\title{
Globalization of Chinese Firms: Theoretical Universalism or Particularism
}

\author{
Ilan Alon, ${ }^{1}$ John Child, ${ }^{2}$ Shaomin $\mathrm{Li},{ }^{3}$ \\ and John R. McIntyre ${ }^{4}$ \\ ${ }^{1}$ Rollins College, USA, ${ }^{2}$ University of Bimingham, UK, ${ }^{3}$ Old Dominion University, USA, and \\ ${ }^{4}$ Georgia Institute of Technology, USA
}

ABstract Research on the globalization of Chinese and other emerging markets' companies has only just begun and is on the verge of taking off. As it does so, additional thought should be given to the ontological and epistemological underpinnings of the theories attempting to capture the phenomenon. Should Western-centric theory prevail? Be adapted? Or abandoned in favour of new indigenous approaches to theorizing, based on context? Finally, should the context itself be the basis of theorizing? While the debate will not stop here, the future may hold a multiplicity of approaches, both indigenous and internationalized, for explaining emerging markets' contexts and, more specifically, for understanding internationalization of their economies and their multinationals. This article provides an overview of the debate on Chinese Theory of Business vs. Theory of Chinese Business, and highlights the contribution of three key articles utilizing a hybrid approach of adapted theory, controlling for the various multinational contexts. We conclude that no theory has a monopoly on explanation and a multi-level, multidisciplinary, and, perhaps, Eastern-centric theory may prove to show great potential in future theories of emerging markets' multinationals.

KEYwords Chinese firms, emerging markets, globalization, indigenous approaches, internationalization, multinational corporations

\section{INTRODUCTION}

The globalization of Chinese business enterprises, in the wake of the rapid ascent of the Chinese economy, has increased substantially. With it comes the question of how to explain Chinese corporate behaviour as an essential component of China's new status as a leading world economic actor. Multiple reasons can be adduced to explain this global ascent: China's enormous growth has concomitantly fuelled its need for resources, both strategic and natural, resulting in differing choices and patterns of investment. China's globalization has been driven, in large measure, by its outbound and inbound foreign direct investment (FDI) 
activities which have evolved rapidly in the past 20 years and have implied varying explanatory frameworks. Once Premier Wen Jaibao announced in 2004 that 'the Chinese government encourages more enterprises to go global', the pace of Chinese outbound investment began in earnest, with foreign acquisitions doubling from 40 in 2003 to 82 in 2006 and reaching a high of 298 in 2009 or some $\$ 73.20$ billion, anticipated to account for roughly $8 \%$ to $9 \%$ of global merger and acquisition activity in 2011 (Williamson \& Raman, 2011). The Chinese government openly encourages Chinese investment abroad, supported by a vast pool of savings and export surplus earnings, in addition to relatively cheap labour.

China is seeking the development of world-class multinational companies with a full range of competencies to explore and exploit opportunities around the world, yielding enhanced technical know-how and access to distant foreign markets (Alon $\&$ McIntyre, 2008). The globalization of Chinese firms, in particular, has garnered increasing attention in the professional literature (Boisot \& Meyer, 2008; Buckley, 2004; Child \& Rodrigues, 2005; Wang, Boateng, \& Hong, 2011; Williamson \& Raman, 2011; Zeng \& Williamson, 2007).

With rapid economic growth in China and the societies with Chinese heritage (Hong Kong, Singapore, and Taiwan), social science researchers have been debating an important question: whether existing theories, which are primarily developed in the setting of the mature economies in the West, are nonetheless relevant and capable of explaining the economic miracles in Chinese societies? Or whether new theories based on the Chinese experience need to be developed (Barney \& Zhang, 2009)? This debate has sharpened in the late 1990s and into the new century as China became the world's manufacturing base and the largest creditor of the U.S.

\section{The Current Debate: Theory of Ghinese Business (Universalism) or Chinese Theory of Business (Particularism)}

At the root of the globalization of Chinese enterprises are epistemological and ontological debates. There are at least two contrasting views in this debate (Barney \& Zhang, 2009; Li \& Nair, 2009).

Some scholars (e.g., Alon, Chang, Fetscherin, Lattemann, \& McIntyre, 2009) believe that existing theories can satisfactorily explain the globalization of Chinese enterprises. Applying institutional (macro, external), resource-based, and internalization (micro, internal) theories to explain internationalization is now commonplace, but studies which seek to combine multiple theoretical approaches can offer a richer explanatory terrain. Rugman (2010: 353) suggested that 'no new theory is needed to explain Chinese outward FDI' and that the theory he developed with Doh in 1981 combines both firm-level and countrylevel factors, which can account for the differing conditions in China. He further 
notes that because Chinese firms cannot buy tacit knowledge, they are not asset-seeking, but rather 'almost entirely' natural resource and market seekers. The research question Rugman poses, in the context of an evolving body of theoretical work, is whether Chinese multinational enterprises can develop firmspecific advantages (technology-based, knowledge-based or managerially derived) or whether Chinese multinational enterprises must rely principally on countryspecific advantages flowing out of an emerging model of state capitalism. Under this set of premises no new theoretical framework would be required to explain Chinese outward FDI and the strategic decisions of its multinational enterprises (Rugman, 2010).

Scholars who assert that China's firm behaviour does not need uniquely Chinese theories argue that, by definition, a theory should be generalizable to different observations across countries. There may be variations in how a theory manifests itself in various settings but a theory such as agency theory, resource-based theory, or institutional theory should be universal. The concept of guanxi, for example, can be studied through the prism of network theory (Child, 2000). Institutional theories can be applied to account for the considerable involvement of Chinese governmental and Party organs in business policy decisions, including those on overseas FDI (Luo, Xue, \& Han, 2010). Institutional support can compensate for the ownership and locational disadvantages of Chinese firms when investing overseas (Voss, Buckley, \& Cross, 2009). Thus, it is possible for research from a wide variety of settings to build on extant research and extend the theories and our understanding of business and management. As such, a call for uniquely Chinese theories is not warranted.

Addressing a similar debate in economics, Qian (2002) proposes a way to examine the applicability of generalized theory. He believes that a well-established field requires three necessary dimensions: perspective (fundamental assumptions), reference (or benchmark, which provides theoretical models), and analytical tools (statistical analysis, case study). Based on these conditions, he concludes that there is no need to create country-specific economics, but scholars with unique experience in a country or region may apply general theories to generate unique and country-specific insights.

On the other hand, researchers have called for more indigenous research to account for context-sensitive research. Tsui (2004) suggested that the North American bias of Chinese management research has hampered our understanding by focusing on context-free conceptualization, where in fact, as Child (2000, 2009) noted, high context cultures such as China's stress national difference. Global management knowledge can be gained through either context-embedded, context-bounded, or context-specific conceptualization (Tsui, 2004). Indeed, the rapid political, economic, and cultural transformations in emerging markets, such as China, present unprecedented opportunities to apply general theories and develop new ones grounded in a new social context. Whether context-specific or 
context-embedded, the inclusion of context requires indigenization (Tsui, 2004, 2009).

In contrast to Tsui (2004), Li and Peng (2008) suggest that purely indigenous theories should be abandoned in favour of theories that integrate both context-free and context-embedded (China-specific) elements. They point out that Chinese theories lack sufficient theoretical rigor, are not likely to be read and tested by others, and tend to be based on conjecture and speculation. Leung (2009) took a less radical position and argued for integration of indigenous theories in different contexts to create universal theories.

\section{THREE ARTICLES ON THE GLOBALIZATION OF GHINESE FIRMS}

There is an opportunity to investigate the validity of mainstream Western theories in China, while maintaining sensitivity to local specifics, in order to broaden the range and applicability of these theories. The resource-based view, industry and institutional theories can be combined to achieve a better understanding of Chinese firms' behaviours. The motivation for this Special Issue arose in part from our desire to better understand the globalization of Asian firms, in general, and Chinese firms, more specifically, and in part by the field's need to theorize about emerging markets, where the traditional assumptions of the firm and the role of the firm in society are not well grounded. This Special Issue received 29 submissions and ended with three which epitomized excellent scholarship with relevance to emerging and transitioning China (about 10\% acceptance rate). The articles in this Special Issue provide a blend of perspectives mostly grounded in the specific culture of Chinese heritage. The articles examine government-controlled firms' internationalization (business groups in China), private firms' OFDI motivations, and family-owned firms' global outreach. Below is a brief overview of the three articles.

\section{State Controlled, Private and Family Owned Business Internationalization}

The first article by Yiu (2011) discusses the unique organizational form of Chinese business groups, marked by internal capital markets, inward linkages, and institutional support, which pose a challenge to traditional MNE theories. In China, business groups account for as much as $60 \%$ to $70 \%$ of the nation's industrial production. The top 100 are in the 'national team' for international expansion, according to the 11 th Five-Year Plan of the Chinese government (Zhang \& Alon, 2010).

Chinese groups, designed to overcome market imperfections, constitute a micro-institutional environment. Building on Dunning's Ownership-LocationInternalization (OLI) and Mathew's Linkage, Leverage, and Learning (LLL) 
frameworks (Mathews, 2006), Yiu is able to show how the specific attributes of Chinese business groups that help in developing multinational advantages which, in turn, lead to either asset exploitation in developing countries or asset augmentation in developed countries. The notion suggested by Ruman earlier, that Chinese firms cannot obtain tacit knowledge, is thus challenged. The author's multi-tier explanation of business group internationalization provides a theoretical framework that future research can test. First, at the organization level, internal capital markets provide the scope economies vertical and horizontal linkages and internalized capabilities. The organization structure of business groups in China alone contribute to the OLI advantages as well as LLL opportunities. Second, the inter-organizational attributes, i.e., inward linkages to the domestic market, constitute a location advantage as well as a linkage to learning. Finally, the institutional support, particularly from the government, provides both location advantages and linkage to learning. On the basis of this model, Yiu makes three propositions that suggest that business groups in China are more able to take advantage of OLI advantages and LLL opportunities.

Yiu seeks to show how OLI and LLL theories apply in a developing country context, by augmenting these two theoretical frameworks of developed country and developing country multinationals, respectively, by focusing on the transmission mechanisms for internationalization. Context is embedded in the research through the examination of China as a particular case study of business group internationalization. Other developing country multinationals comprising business groups may follow similar patterns and should be examined in future research.

The second article, written by Lu, Liu, and Wang (2011), while investigating private firms, is similar to the first in that it too evaluates the internationalization of Chinese firms on multiple levels: firm, industry, and country. The 'strategy tripod' framework of emerging economies' multinationals is used (Peng, 2006; Yamakawa, Peng, \& Deeds, 2008): resource-based, industry-based, and institution-based explanations are used together to explain strategic- and market-seeking motivations for OFDI.

At the firm level, technology-based competitive advantage and export experience directly affects the internationalization motive, not internationalization, per se. At the industry level, R\&D intensity and industry competition affect internationalization motive directly and indirectly by moderating the effect of resources on internationalization. At the institutional level, government policies affect internationalization motive directly and through its moderating effect on the linkage between resources and internationalization motive. At the core of the research are the resource-based theory of the firm, competitive theory of the industry, and institutional theory of the country. In this way, the article typifies the multi-level analysis espoused by $M O R$.

Of 1,200 private firms sampled, 868 replied and completed questionnaires $(72 \%)$. The findings largely support their hypotheses and show that strategic asset 
and market-seeking motivations are not mutually exclusive. Technology firms will particularly seek strategic assets, while market-seeking firms will likely export ahead of investment. Government regulation promotes investment both directly and indirectly through company resources. The empirical evidence on the role of government in Chinese firms' internationalization intention reinforces Yiu's hypothesis on the role of the institutional environment.

The third and final article in this issue by Liu, Lin, and Cheng (2011) investigates the role of family ownership in international involvement of Taiwanese firms, building on the Dunning OLI framework and Erdener and Shapiro's (2005) application of OLI to Chinese family businesses. Using longitudinal data on 179 high tech firms, the authors find that family firms that are not closely held or excessively controlled are more likely to go global. Furthermore, high discretion organizational slack accentuates the negative impact of family ownership on internationalization. By examining the particular micro-context of the family business and the macro-context of another ethnic Chinese area, Taiwan, the article pushes the boundaries of theory testing and shows how traditional theories of the firm (particularly ones relating to family firms) can explain internationalization in different contexts.

\section{DISGUSSION}

Taken together, the three Special Issue articles investigate three prevalent forms of business internationalizing from Chinese dominated areas: SOE-led business groups, private firms, and family-owned firms. They collectively confirm that multiple levels of analysis need to be used in explaining internationalization, and that traditional theories of the firm need to be augmented to fit the context of emerging markets, in general, and China more specifically.

Among the organizational variables used in the articles of this issue and deemed relevant in these research papers are: scope economies, vertical and horizontal linkages, internalization, technology-based competitive advantage, export experience, diversification, family ownership, excess family control, and high discretionary slack. Industry variables include inter-organizational linkages, industry competition, and industry R\&D intensity. Institutional environment includes government support and regulations, both direct and indirect.

The salient features of Chinese firms and their globalization make them unique but also allow for easy extension to multinational enterprises in other emerging economies. As market-seekers, Chinese firms respond to the export orientation of government policies. Considering the consumer electronics global market is enough to demonstrate this attribute. Other firms, especially in materialsprocessing sectors, are also certainly resource-seeking, responding to the resource paucity of the home economy's natural resources which makes it a national strategic concern. The validity of this feature is made evident in the approach pursued 
by firms such as China National Offshore Oil Corporation (CNOOC) and China Petrochemical Corporation (SINOPEC).

Perhaps one of the most salient features of Chinese firms is that their organizations are shaped by an institutional environment characterized by centralized state control, authoritarian culture, and relation-based management (Maurer \& $\mathrm{Li}, 2006)$. Many research questions are important to pursue. When Chinese firms go to a country with a different institutional environment (such as more democratic and rule-based), how do they adjust their organization to operate efficiently? More specifically, how do Chinese firms manage organizational learning (e.g., between exploration and exploitation) (March, 1991), and how do they adjust their organization design to a foreign country (Judge \& Li, 2007)? Studying these issues will not only shed light on the management and organization of Chinese firms going abroad, but also contribute to our understanding on how the institutional environment affects organizational learning and organization design.

The recent acquisition of firms in the European Union and North America by Chinese firms demonstrates a desire to seek and acquire assets focused on intangible assets, brands, distribution networks, and proprietary industrial and intellectual property. Gaining an understanding of Chinese global firms cannot be achieved solely with a body of theory developed for Western companies and in a developed industrial context. There are features that are specific or unique to the Chinese corporate context. While developed countries' multinational enterprises have created best governance practices more suited to a stable, lower-risk and perhaps transparent operational environment with a lesser level of government involvement, Chinese firms are seemingly facile at coping with a more complex institutional environment in which market and state are interpenetrated and in which corporate and government are interlinked. The initial resource-seeking emphasis of Chinese multinationals has yielded a greater capacity in managing troublesome infrastructural projects. This corporate experience abroad in resource-seeking endeavours but also in dealing with expanding domestic markets has not been neutral and Chinese firms have learned in expanding their focus to other activity zones (Agtmael, 2007).

Cultural distance, as well as capital requirements, remains an issue for emerging market firms as they globalize (Morck, Yeung, \& Zhao, 2007). Mergers and acquisitions may play a role in diminishing the impact of potential corporate and national cultural clashes. The process of globalization is also one of strategic and structural adaptation to an expanding geographical horizon and rapid-paced technological and corporate governance change. Chinese multinationals will not be exempt from this adaptive process but will address it in ways that are unique to their home culture and, in so doing, will incline us to revisit our traditional theoretical frameworks to grasp the outbound move of Chinese firms. This may suggest the need of a Chinese theory of globalization. 
Globalizing Chinese firms, state-owned or private, have learned strategic and managerial lessons in a unique path of adaptation. Following China's accession to the World Trade Organization in 2001, Chinese firms were allowed to acquire overseas assets. This led to a subsequent shift in strategy for a significant number of companies seeking to enhance their market shares abroad and to consolidate their home market positions, thus boosting domestic consumption in the aftermath of the global recession (Kim, 2009). Chinese firms have thus evolved from a policy of yimjin lai (引进来 'pull in') in which the government traded access to China's market for technologies from abroad to an approach best characterized as zou chuqu (走出去 rushing or swarming out).

Theories capable of explaining Chinese firms' internationalization may be more easily extended to other emerging economies' MNEs. The call by Tsui (2004, 2009) for more indigenous research was partly answered in this issue by augmenting traditional theory and taking into account the unique features of Chinese globalization. The contributions in this special issue are a step forward in defining a growing body of literature which seeks to elucidate the complex and perennial issues of universalism versus particularism. Much more research is needed to discuss, debate, and resolve this issue.

\section{CONCLUSION}

The debate between theoretical universalism or particularism will not end here. Emerging markets are pushing the boundary of theory examination and testing the assumptions of our management theories. Theories particular to emerging markets may emerge, but those who are able to embed the context in the content of the theory may be able to generalize across cultural, institutional, and national boundaries. From the articles in this issue, one may infer that no single theory has a monopoly on explanation and that multi-theoretic, multi-level, and indigenized frameworks may be used profitably in explaining social phenomena outside the environments in which these theories were conceived.

\section{REFERENCES}

Agtmael, A. V. 2007. The emerging markets century: Hoze a new breed of zoorld-class companies is over-taking the world. New York: Free Press.

Alon, I., Chang, J., Fetscherin, M., Lattemann, C., \& McIntyre, J. R. (Eds.), 2009. China rules: Globalization and political transformation. New York: Palgrave MacMillan.

Alon, I., \& McIntyre, J. R. (Eds.). 2008. The globalization of Chinese enterprises. New York: Palgrave MacMillan.

Barney, J. B., \& Zhang, S. 2009. The future of Chinese management research: A theory of Chinese management versus a Chinese theory of management. Management and Organization Revieze, 5(1): 15-28.

Boisot, M., \& Meyer, M. W. 2008. Which way through the open door? Reflections on the internationalization of Chinese firms. Management and Organization Revieze, 4(3): 349-365. 
Buckley, P. 2004. The role of China in the global strategy of multinational enterprise. Joumal of Chinese Economics and Business Study, 2: 1-25.

Child, J. 2000. Theorizing about organization cross-nationally. In J. L. Cheng \& R. B. Peterson (Eds.), Advances in international comparative management, $V_{0}$ l. 13: 27-75. Grecnwich, CT: JAI Press.

Child, J. 2009. Context, comparison, and methodology in Chincse management research. Management and Organization Review, 5(1): 57-77.

Child, J., \& Rodrigues, S. B. 2005. The internationalization of Chinese firms: A case for theoretical extension. Management and Organization Review, 1(3): 381-410.

Erdener, C., \& Shapiro, D. M. 2005. The internationalization of Chinese family enterprises and Dunning's eclectic MNE paradigm. Management Organization Revieze, 1(3): 411436.

Judge, W., \& Li, S. 2007. Effects of governance environment on organizational structure and process. Stcamboat Springs, CO: Organization Science Winter Conference.

Kim, 1. 2009. Inward and outward internationalization of Chincse firms. SERI Quarterly Archives, 2(2): 23-30. Scoul: Samsung Economics Rescarch Institutc.

Leung, K. 2009. Never the twain shall mect? Integrating Chinese and western management practiccs. Management and Organization Review, 5(1): 121-129.

Li, S., \& Nair, A. 2009. Asian corporate governance or corporate governance in Asia? Corporate Governance: An International Revieze, 17(4): 407-410.

Li, Y., \& Pcng, M. W. 2008. Developing theory from strategic management research in China. Asia Pacific Journal of Management, 25: 563-572.

Liu, Y., Lin, W.-T., \& Cheng, K.-Y. 2011. Family ownership and the international involvement of Taiwan's high-technology firms: The moderating effect of high-discretion organizational slack. Management and Organization Revieze, 7(2): 20l-222.

Lu, J., Liu, X., \& Wang, H. 2011. Motives for outward FDI of Chinese private firms: Firm resources, industry dynamics, and government policies. Management and Organization Revieze, $7(2): 223-248$.

Luo, Y., Xue, Q., \& Han, B. 2010. How emerging market governments promote outward FDI: Experience from China. Journal of World Business, 45: 68-79.

March, J. 1991. Exploration and exploitation in organization lcarning. Organization Science, 2(1): 71-87.

Mathews, J. A. 2006. Dragon multinationals: New players in the 21 st century globalization. Asia Pacific Joumal of Management, 23: 5-27.

Maurer, S., \& Li, S. 2006. Understanding expatriate manager performance: Effects of governance cnvironment on work relationships in relation-based cconomics. Human Resource Management Review, 16: 29-46.

Morck, R., Ycung, B., \& Zhao, M. 2007. Perspectives on China's outward foreign dircet investment. Journal of International Business Studies, 39: 337-350.

Peng, M. W. 2006. Global strategy. Cincinnati, $\mathrm{OH}$ : Thomson South-Western.

Qian, Y. 2002. Understanding contemporary economics (in Chinese). Economic and Social System Comparison, 2. [Last accessed 12 April 2011.] Available from URL: http://202.199.160.3/ experience/2007-1 l-25/301.html

Rugman, A. 2010. Book review: Globalization of Chinese enterprises. The Intemational Trade Journal, 24(3): 352-354.

Tsui, A. S. 2004. Contributing to global management knowledge: A case for high quality indigenous rescarch. Asia Pacific Journal of Management, 21: 491-513.

Tsui, A. S. 2009. Editor's introduction - Autonomy of inquiry: Shaping the future of emerging scicntific communitics. Management and Organization Review, 5(1): 1-l4.

Voss, H., Buckley, P., \& Cross, A. 2009. An assessment of the effects of institutional change on Chinese outward direct foreign investment activity. In I. Alon, J. Chang, M. Fetscherin, C. Lattemann \& J. McIntyre (Eds.), China rules: Globalization and political transformation: 135-165. London: Palgrave Macmillan.

Wang, C., Boateng, A., \& Hong, J. 2011. What drives internationalization of Chinese firms: Three theoretical explanations. Working paper. Nottingham University School of Business, China.

Williamson, P. J., \& Raman, A. P. 2011. How China reset its global acquisition strategy. Harvard Business Review, 89(4): 109-114. 
Yamakawa, Y., Peng, M. W., \& Deeds, D. L. 2008. What drives new ventures to internationalize from emerging to developed economies? Entrepreneurship Theory and Practice, 32(1): 59-82.

Yiu, D. W. 2011. Multinational advantages of Chinese business groups: A thcoretical cxploration. Management and Organization Revieze, 7(2): 249-277.

Zeng, M., \& Williamson, P. J. 2007. Dragons at your door: How Chinese cost innovation is disrupting global competition. Cambridge, MA: Harvard Business Press.

Zhang, W., \& Alon, I. (Eds.), 2010. A guide to the top 100 companies in China. Singapore: World Scientific.

Ilan Alon (ialon@rollins.edu) is Cornell Chair of International Business and Director of The China Center at Rollins College, and Visiting Scholar \& Asia Fellow at Harvard University. He has published 25 books, and over 100 peer-reviewed articles and chapters. His recent co-edited books on China include The Globalization of Chinese Enterprises (Palgrave, 2008), China Rules (Palgrave, 2009), and Chinese International Investments (Palgrave, 2011).

John Child (j.child@bham.ac.uk) is Professor Emeritus at the University of Birmingham, UK. He also has visiting positions in Brazil and China. He is a past editor-in-chief of Organization Studies and a former Senior Editor of Management and Organization Reviewe. His interests are in the fields of organization and international business. He has undertaken research and consultancy on the management and organization of foreign-invested firms in China and on challenges facing SMEs entering foreign markets.

Shaomin Li (sli@odu.edu) is the E.V. Williams Fellow and Professor of International Business at Old Dominion University. He is the Executive Editor of Modern China Studies and a former Associate Editor of Corporate Governance: An International Review. He received Virginia Governor's Outstanding Faculty Award in 2008. His research focuses on the governance environment in countries undergoing rapid political and economic transitions.

John R. McIntyre (john.mcintyre@mgt.gatech.edu) is Professor of Management and International Affairs and founding Executive Director of the Georgia Tech Center for International Business Education and Research, Georgia Institute of Technology. His research has focused on sustainable development in the multinational enterprise, comparative management, the rise of Chinese multinationals, and the shifting paradigms of business education in emerging economies. He has over 80 publications relating to these topics and has authored and co-edited 11 books. He is the 2009 recipient of the Georgia Governor's International Education Award.

Manuscript received: January 21, 2011

Final version accepted: May 17, 2011

Accepted by: Anne S. Tsui 